\title{
AKTIVITAS DAKWAH K.H. MUHAMMAD YAHYA DI CIMAHI TAHUN 1947-2009
}

\author{
Hendro Kartika J, Ajid Thohir \\ Fakultas Adab dan Humaniora, Universitas Islam Negeri \\ Sunan Gunung Djati Bandung \\ Email: hendro.kawan@gmail.com
}

\begin{abstract}
K.H. Muhammad Yahya (commonly known as Abuya Sepuh or Abuya Mamad) is an Islamic scholar from Cimahi. He is a Da'i, Murshid Tariqah, and also a Judge in the Religious Courts. He was the founder of Pesantren Darussurur Cimahi, and extensively wrote Sundanese nadhom, and participated in spreading the Islamic da'wah in the City of Cimahi. He contributed to education, social, religion, and Islamic da'wah. This study aims at finding out the biography of K.H. Muhammad Yahya and his Da'wah Activities in Cimahi. The method used is a historical research method which consists of four stages, namely heuristics, criticism, interpretation, and historiography. Based on the results of the study, it can be concluded that, first, K.H. Muhammad Yahya was born in 1917 and died in 2009 in the Main Village, Cimahi. He is the son of K.H. Muhammad Azhari and Hj. Khadijah, his nasab through his father reached Maulana Syarif Hidayatullah. His educational genelogy was formed from the environment and education he got from various teachers, such as Habib Ali al-Attas (Jakarta), Habib Abdullah Bilfaqih (Malang), Muhaddist Assayid Alwi bin Abbas al-Malik (Mecca), K.H. M. Kurdi (Cibabat), K.H. M. Zarkasyi (Cibaduyut). Second, the da'wah activities K.H. Muhammad Yahya in Cimahi covers several aspects and media, namely da'wah through educational institutions with the establishment of pesantren Darussurur (1947-2009), da'wah through religious teachings (1947-2009), da'wah through Tariqah (TQN) (1960s), and da'wah through writing (1979-2009), in which he wrote and translated Arabic books composed in the form of Sundanese nadhom, such as Nadhom Shoibul Iman, Aqidatul awam, Lawang Setan, and many others.
\end{abstract}

Keywords: Ulama Biography, Educational Geneology, Da'wah Activity, Ahlussunnah wal Jama'ah, Cimahi 


\section{Pendahuluan}

Dalam sejarah umat Islam, ulama memegang peranan yang terbilang penting dan signifikan dalam kehidupan umat, tidak hanya dalam hal dakwah keagamaan, tetapi juga mencakup bidang-bidang lainnya, seperti sosial, politik, dan budaya, ${ }^{1}$ hal ini memposisikan ulama sebagai figur yang Istimewa diatas panggung sejarah umat Islam, terutama di Indonesia. ${ }^{2}$ Diatas peranannya sebagai elite keagamaan, ulama berperan mulai dari tempat bertanya mengenai ajaran keagamaan, sampai kepada menyelesaikan problem-problem yang berkembang di masyarakat dalam ruang lingkup yang luas. Bahkan, ulama dipandang sebagai rujukan umat, dimana ulama merupakan figur yang diidealisasikan oleh umat. ${ }^{3}$ Ulama posisinya di masyarakat bertindak sebagai "al-Umma al-Wasatan" yaitu sebagai teladan bagi masyarakat di tengah arus kehidupan yang serba kompleks, yang penuh dengan dinamika perubahan, tantangan dan pilihan-pilihan yang terkadang sangat dilematis dan problematis di tengah masyarakat, ${ }^{4}$ sehingga, ulama dalam posisi ini hadir memberikan penerangan dan mengajak kepada amal ma'ruf nahyi munkar (menyeru kepada yang baik dan mencegah dari yang buruk).

Dalam lingkup masyarakat Indonesia, cenderung lebih banyak mengenal ulama-ulama yang memiliki caliber luas dan popular, terkadang ulama-ulama lokal kurang mendapat perhatian dan sorotan, meskipun memiliki peran dan kontribusi yang signifikan bagi masyarkaat sekitarnya. Salah satu ulama lokal yang aktif pada masanya dalam berdakwah serta mengajarkan ajaran Islam pada masyarakat sekitarnya adalah K.H. Muhammad Yahya, beliau lahir di Desa Utama, Cimahi pada tahun 1917, ayah beliau bernama KH. Muhammad Azhari, dan ibunya bernama Hj. Khodijah. ${ }^{5}$

K.H. Muhammad Yahya selain sebagai seorang $d a$ 'I atau pendakwah, beliau juga merupakan seorang Mursyid Thariqah Qodiriyah wa Naqsabandiyah, dan juga merupakan seorang Hakim di Pengadilan Agama Bandung, hal ini menjadi nilai lebih bagi beliau dalam proporsi dan peranannya sebagai seorang ulama, dimana beliau memahami metode dakwah dan keilmuan Islam, mendalami ilmu tasawuf, dan menguasai hukum-hukum Islam (tasyri wal ahkam).

\footnotetext{
${ }^{1}$ Agus Iswanto, Sejarah Intelektual Uslam Nusantara: Reformulasi Tradisi di Tengah Pembaharuan, (Balai Litbang Agama Jakarta: Jurnal Lektur Keagamaan, 2013), hlm. 456.

${ }^{2}$ Moeflich Hasbullah, Sejarah Sosial Intelektual Islam di Indonesia, (Bandung: Pustaka Setia, 2012), hlm. 20.

${ }^{3}$ M. Yasir Nasution, Peran Strategis Ulama dalam Pengembangan Ekonomi Syariah, (Surakarta: Jurnal Human Falah IAIN Surakarta, 2014), hlm. 18.

${ }^{4}$ H. Munzier dan H. Harjani, Metode Dakwah, (Jakarta: Kencana, 2009), hlm. 3.

${ }^{5}$ Buya Anom, Biografi Syeikhina Abuya KH Muhammad Yahya bin KH Muhammad Azhari, (Bandung: Ponpes Darussurur), hlm. 5.
} 
Selain itu, beliau juga banyak menulis nadhom yang menjadi pondasi serta konstruk pemikiran, dan warisan intelektualitas keilmuan beliau sampai hari ini, dimana beliau banyak menulis dan menerjemahkan kitab-kitab berbahasa Arab, yang digubah kedalam nadhom-nadhom Sunda, yang menjadi salah satu pendekatan dakwah beliau kepada masyarakat. Karya dan ajarannya masih dapat dinikmati hingga hari ini oleh para pencari ilmu dan umat Islam pada umumnya, meski beliau telah meninggal pada tahun 2009, dan di makamkan di kediaman beliau di Utama, Cimahi yang sekarang terkenal dengan nama, Maqom Qomar. ${ }^{6}$

Beliau merupakan tokoh agamawan, mursyid thariqah, dan elite pemerintahan yang turut mewarnai percaturan dakwah Islam di kota Cimahi. Bukti keseriusan, ketekunan dan kegigihan dakwahnya termanifestasi pada pondok pesantren ${ }^{7}$ yang beliau dirikan pada tahun 1947 sebagai media, pusat pengajaran dan penyebaran dakwah keislaman, yaitu Pondok Pesantren Darussurur di Desa Utama, Cimahi, yang hingga kini telah mempunyai cabang sampai 40 lebih pesantren dan Majelis Ta'lim. ${ }^{8}$ Dan langkah ini, mengawali peran penting beliau dalam bidang pendidikan, sosial, keagamaan, dan dakwah keislaman bagi masyarakat kota Cimahi.

\section{Studi Pustaka}

Rencana penelitian yang dilakukan penulis ini tidak semata-mata dibuat begitu saja tanpa melihat karya dan tulisan lain sebagai pembanding dan pemberi ide baru. Penulis telah melakukan observasi guna mencari sumber-sumber apa saja yang terkait dengan topik dan judul yang penulis teliti. Hasil dari observasi tersebut, setidaknya sampai saat ini penulis telah menemukan beberapa literatur yang menginformasikan atau berkaitan dengan Aktivitas Dakwah K.H. Muhammad Yahya di Cimahi. Adapun beberapa karya atau tulisan ilmiah tersebut di antaranya sebagai berikut:

Pertama, buku yang ditulis oleh Abuya Anom KH. Muhammad Sulaiman Jazuli, yang berjudul Biografi Syeikhina Abuya KH Muhammad Yahya bin KH Muhammad Azhari. ${ }^{9}$ Buku tersebut membahas mengenai Biografi K.H. Muhammad Yahya, menjelaskan mengenai riwayat hidup beliau dari mulai lahir, menimba ilmu, berdakwah dan mendirikan pesantren hingga beliau meninggal. Objek yang menjadi bahan penelitian dari buku ini

\footnotetext{
${ }^{6}$ Buya Anom, Biografi Syeikhina Abuya..., hlm. 33.

7 Dalam bukunya Zamakhsyari Dhofier, Tradisi Pesantren: Studi Tentang Pandangan Hidup Kyai (2011), Pesantren merupakan bagian serta elemen paling penting yang tidak terlepaskan dari peranan serta figur seorang Kyai dalam aktualisasi peranan status and rolenya di tengah masyarakat, terkhusus dalam bidang dakwah keagamaan.

${ }^{8}$ Buya Anom, Biografi Syeikhina Abuya ..., hlm. 7-8.

${ }^{9}$ Buya Anom, Biografi Syeikhina Abuya KH Muhammad Yahya bin KH Muhammad Azhari, (Bandung: Ponpes Darussurur).
} 
memang sama dengan penulis yaitu K.H. Muhammad Yahya, namun, dalam subjek kajian penelitian yang penulis ambil cukup berbeda dari yang telah dibahas, dimana penulis lebih menekankan pada aktivitas dakwah K.H. Muhammad Yahya sendiri, tidak hanya Biografinya saja. Sehingga, dapat dimungkinkan setelah selesai, penelitian ini menjadi pelengkap dari tulisan yang sudah ada.

Kedua, skripsi yang ditulis oleh Nikmah Amini, mahasiswa UIN Bandung, yang berjudul Aktivitas KH. Ahmad Faqih Tahun 1957-2000 M di Cianjur. ${ }^{10}$ Skripsi tersebut membahas mengenai Aktivitas Dakwah dan Keagamaan KH. Ahmad Faqih di Cianjur melalui Pesantren Miftahulhuda AlMusri' yang didirikannya. Dalam skripsi ini, penulis banyak merujuk struktur penelitian Nimah mengenai Aktivitas K.H. Ahmad Faqih dan menjadi contoh serta gambaran penelitian serta penulisan skripsi yang penulis tempuh. Diluar dari itu, terdapat perbedaan yang signifikan terhadap penelitaian yang penulis ambil dengan Nimah, dimana letak perbedaannya terdapat pada objek kajiannya, dimana tokoh yang Nimah teliti dengan yang penulis teliti tentu berbeda, sedang dari subjek penelitian yaitu mengenai "Aktivitas Dakwah" menjadi acuan dasar struktur penelitian penulis dalam meneliti Aktivitas Dakwah K.H. Muhammad Yahya di Cimahi.

Dalam tulisan-tulisan sebelumnya telah ada yang mengkaji mengenai figur K.H. Muhammad Yahya, namun, belum dijelaskan begitu mendalam mengenai perjalanan dakwah dan aktivitas dakwahnya, sehingga cukup terlihat perbedaan fokus dan objek penelitian yang diambil antara penulis dan karya tulis sebelumnya. Sehingga, kedepannya penelitian ini dimungkinkan akan menyempurnakan tulisan-tulisan sebelumnya. Agar menghasilkan sejarah dan studi tokoh terkhusus sejarah dakwah Islam K.H. Muhammad Yahya yang lebih lengkap dan komprehensif.

\section{Metodologi Penelitian}

Sejarah merupakan peristiwa penting yang terjadi dimasa lalu yang dilakukan oleh manusia sebagai objek kajiannya. Dalam rangka merekonstruksi sejarah atau peristiwa masa lalu, seorang sejarawan tidak begitu saja melakukan penelitian tanpa dipandu oleh beberapa prosedur penelitian yang telah mutlak diberlakukan, agar menghasilkan penelitian sejarah yang ilmiah, kredibel dan otentisitas serta orisinalitasnya terjamin.

Adapun tahap-tahap metode sejarah atau langkah-langkah dalam penelitian sejarah diantaranya yaitu, terdiri dari tahap heuristik, tahap kritik, tahap interpretasi dan tahap historiografi.

\footnotetext{
${ }^{10}$ Nikmah Amini, Aktivitas KH. Ahmad Faqih Tahun 1957-2000 M di Cianjur, (Skripsi UIN Bandung, 2015).
} 


\section{Heuristik}

Dalam prosedur pengumpulan sumber penelitian atau Heuristik, ${ }^{11}$ penulis telah melakukan berbagai tahap pencarian sumber. Dari mulai penjajakan hingga penelusuran sumber. Dalam proses penyusunan penelitian ini, penulis menghimpun sumber-sumber yang berkenaan dengan topik penelitian penulis, baik sumber tertulis maupun lisan. Kitab kumpulan nadhom Sunda karangan K.H. Muhammad Yahya, Kitab Mazmu fi alNadhomaati al-Arobiyah Darussurur, dibukukan oleh Muhammad Abd alQadir bin K.H. Abdullah Qasim Shaleh, (Bandung: Ma'had Darussurur, 2007). Buku karangan Abuya Anom K.H. Muhammad Sulaiman Jazuli, Biografi Syeikhina Abuya K.H. Muhammad Yahya bin K.H. Muhammad Azhari, (Bandung: Ponpes Darussurur).

Serta Wawancara K.H. Muhammad Sulaiman Jazuli (anak ke-15 dan pimpinan Pondok Pesantren Darussurur Pusat), dilaksanakan pada 19 Mei 2018 di kediamannya di Pondok Pesantren Darussurur Pusat (LagadarBandung). Wawancara Muhammad Samsudin (kuncen Maqam Qomar, Makam Keluarga K.H. Muhammad Yahya), dilaksanakan pada 22 Februari 2019 di Maqam Qomar (Utama-Cimahi). Wawancara K.H. Jalaluddin Suyuthi (menantu dan pimpinan SD, SMP, SMK Plus Darussurur), dilaksanakan pada 23 Junin 2019 di SMP Plus Darussurur (Utama-Cimahi). Wawancara Ustadz Irfan (cucu dari K.H. Muhammd Yahya), dilaksanakan pada 23 Februari 2019 di kediaman beliau Pondok Pesantren Darussurur 27 (Lagadar-Bandung).

\section{Kritik}

Kitab Mazmu fi al-Nadhomaati al-Arobiyah Darussurur merupakan kitab yang berisi kumpulan nadhom-nadhom karya K.H. Muhammad Yahya, yang di bukukan oleh keturunan beliau Muhammad Abd al-Qadir bin K.H. Abdullah Qasim Shaleh atas seizin K.H. Muhammad Yahya pada tahun 2007 di Ma'had Darussurur, yang didalamnya beisi kurang lebih ada sekitar 50 nadhom karangan K.H. Muhammad Yahya, maupun terjemahan (syarakh), dengan aksara Arab dan Pegon (Arab-Sunda). Beberapa nadhomnya seperti Nadhom Lawang Setan (bukan terjemahan), Nadhom Sateuacan Kulem (bukan terjemahan, ditulis pada 1400H/1979M), Nadhom Aqidatul Awam (terjemahan), Nadhom Syuabul Iman (terjemahan), Nahdom Azkiya (terjemahan). Kitab ini juga menjadi pegangan pondok pesantren, dan termasuk kedalam sumber primer karena merupakan karya K.H. Muhamamad Yahya.

\footnotetext{
${ }^{11}$ Menurut Notosusanto (1971: 18), heuristik atau heuristis berasal dari bahasa Yunani heuristikein, yang memiliki arti yang sama dengan to find dalam bahasa Inggris yang memiliki arti menemukan. Pada tahapan ini dilakukan langkah atau kegiatan penjajakan, pencarian, dan pengumpulan sumber-sumber yang akan diteliti, baik yang terdapat di lokasi penelitian, berupa temuan benda maupun sumber tulisan dan lisan. Lihat Sulasman, Metode Penelitian Sejarah, (Pustaka Setia, Bandung, 2014), hlm. 93.
} 
Buku Biografi Syeikhina Abuya K.H. Muhammad Yahya bin K.H. Muhammad Azhari merupakan karangan Abuya Anom K.H. Muhamamd Sulaiman Jazuli yang perukan keturunan serta pelanjut kepemimpinan K.H. Muhammad Yahya di Pondok Pesantren Darussurur. Buku ini berisi mengenai biografi dan perjalanan hidup K.H. Muhammad Yahya, dan menjadi rujukan figur K.H. Muhammad Yahya, dan termasuk kedalam sumber primer karena ditulis oleh orang yang dekat dan mengenal langsung pribadi K.H. Muhammad Yahya.

Wawancara K.H. Muhammad Sulaiman Jazuli (anak ke-15 dan pimpinan Pondok Pesantren Darussurur), Muhammad Samsudin (kuncen Maqam Qomar), dan K.H. Jalaluddin Sayuthi (menantu dan pimpinan SD, SMP, SMK Plus Darussurur), ketiganya termasuk kedalam sumber primer, karena ketiganya merupakan orang-orang terdekat dan mengenal langsung K.H. Muhamamd Yahya.

\section{Interpretasi}

Dalam proses penafsiran sejarah atas judul yang penulis teliti, mengenai "Aktivitas Dakwah K.H. Muhammad Yahya di Cimahi Tahun 1947-2009 ini penulis menggunakan Penafsiran "Great Man Theory"12 sebagai dasar tafsiran penulis dalam memaparkan mengenai aktivitas dan peranan dakwah K.H. Muhammad Yahya di Cimahi dalam mengembangkan ajaran Islam, dimana sebagaimana dijelaskan dalam "Great Man Theory" bahwa tokoh-tokoh orang besar merupakan faktor penyebab dan motor penggerak utama dalam perkembangan sejarah. Selain teori orang besar, penulis juga memadukan data yang ada dengan mengikuti konstruk "Satatus and Role Theory", ${ }^{13}$ dimana sebagai pengukuhan interpretasi ketokohan dan kewenangan figur tokoh yang penulis teliti. Dimana, beliau memiliki kedudukan atau ketokohan di masyarakat dan memiliki role atau peran yang berjalan di masyarakat.

Selain itu, penulis juga menafsirkan berdasarkan fakta-fakta sejarah yang telah penulis temukan dilapangan pada tahap heuristik lalu. Berdasarkan fakta yang penulis temukan dilapangan, penulis menafsirkan bahwa aktivitas

\footnotetext{
${ }^{12}$ Great Man Theory, merupkan teori sejarah yang menyandarkan motor penggerak dan penyebab terjadinya sejarah kepada Tokoh Besar atau Orang Besar. Teori ini dikemukakan oleh Thomas Charley dan James A. Froude, dimana mereka beranggapan bahwa orang-orang besar seperti para negarawan, kaisar, raja, jendral dan para nabi termasuk juga tokoh agamawan seperti alim ulama, mereka merupakan factor pemicu terjadinya peristiwa sejarah. Lihat Sulasman, Metode Penelitian Sejarah, (Pustaka Setia, Bandung, 2014), hlm. 125-126.

${ }^{13}$ Status and Role Theory, merupakan tori sosial yang mengacu pada kepemilikan status dan peranan seseorang dalam masyarakat, dimana seorang tokoh memiliki kedudukan dan kewenangannya tersendiri dalam interaksi sosial di masyarakat tempat ia tinggal, untuk mendapat dan melaksanakan setatus dan peranannya demi kelancaran siklus sosial. Lihat Astrid S. Susanto, Pengantar Sosiologi dan Perubahan Sosial, (Binacipta, IKAPI, 1985), hlm. 75-76.
} 
dakwah K.H. Muhammad Yahya mencakup beberapa aspek dan media, yaitu melalui lembaga pendidikan, ceramah keagamaan, tarekat, dan karya tulisnya, yang kesemuanya menjadi dasar kontribusi beliau dalam beberapa bidang, seperti pendidikan, sosial, keagamaan, dan dakwah keislaman. Yang hingga kini termanifestasikan pada pondok pesantren yang beliau dirikan, yang beliau beri nama Pondok Pesantren Darussurur yang hingga kini menurut putera beliau (Buya Anom) sudah memiliki anak cabang hingga 40 lebih. Selain didirikannya pondok pesantren sebagai simbol keseriusan beliau dalam berdakwah mengembangkan ajaran Islam, beliau juga aktif ceramah baik di sekitar pesantren, daerah Cimahi, Bandung juga keluar kota seperti Jakarta, Bogor, Kerawang, Malang, serta menulis nadhom-nadhom berbahasa Sunda sebagai media dakwah beliau, yang secara langsung pula menjadi asas konstruk pemikiran beliau dalam ajaran Islam.

\section{Historiografi}

Dalam penelitian ini, penulis menguraikan biografi K.H. Muhammad Yahya, dari mulai riwayat hidup dan kepribadian, riwayat pendidikan dan genelogi keilmuan, kemudian aktivitas dakwah K.H. Muhammad Yahya, mulai dari dakwah melalui lembaga pendidikan, ceramah keagamaan, thariqah, dan tulisan-tulisan K.H. Muhammad Yahya.

\section{Pembahasan}

Ulama merupakan figur yang paling sentral dalam usaha dakwah dan pengembangan Islam di Indonesia, ulama juga menjadi salah satu aktor penting bagi sejarah Islam Indonesia. Sejak abad ke-7 hingga abad ke-21, ulama menjadi kelompok elit sosial religious yang memiliki peran yang begitu signifikan bagi sejarah dakwah Islam di Indonesia. ${ }^{14}$

Salah satu ulama yang turut serta dalam mewarnai dakwah keislaman adalah K.H. Muhammad Yahya, beliau merupakan seorang pendakwah ( $\left.d a^{\prime} i\right)$, Mursyid Thariqah dan juga Hakim di Pengadilan Agama, selain itu beliau juga banyak menulis nadhom-nadhom sunda, dan juga menerjemahkan serta mensyarakh kitab-kitab berbahasa Arab keadalam bahasa Sunda.

\footnotetext{
${ }^{14}$ Moeflich Hasbullah, Sejarah Sosial Intelektual..., hlm. 19.
} 


\section{Riwayat Hidup dan Kepribadian K.H. Muhammad Yahya}

K.H. Muhammad Yahya ${ }^{15}$ atau yang lebih banyak dikenal dengan Buya Sepuh ${ }^{16}$ juga Buya Mamad merupakan seorang ulama serta mursyid tarekat ${ }^{17}$ yang besaral dari Cimahi, beliau merupakan anak dari pasangan K.H. Muhammad Azhari dengan Hj. Khodijah, yang dilahirkan pada hari Ahad tanggal 1 Desember 1917 M bertepatan dengan 17 Shafar 1336 H di Bandung, Jawa Barat. ${ }^{18}$

K.H. Muhammad Azhari atau Mama Eyang Azhari merupakan seorang ulama sekaligus lurah terhormat di daerah tempat beliau tinggal (di Desa Utama, Cimahi), ${ }^{19}$ dan secara genelogi (nasab), silsilah beliau secara vertikal sampai kepada Maulana Syarif Hidayatullah, yang merupakan seorang ulama juga raja yang memiliki jasa besar dalam proses Islamisasi di Jawa Barat, terkhusus wilayah Cirebon dan Banten, ${ }^{20}$ bahkan, silsilah K.H. Muhammad Yahya jika diteruskan hingga keatas akan sampai kepada Nabi Muhammad SAW. ${ }^{21}$ Nasab K.H. Muhammad Yahya dari garis ayah melalui Syarif Hidayatullah (Sunan Gunung Djati).

1. Maulana Syarif Hidayatullah $(1448 \mathrm{M})^{22}$

${ }^{15}$ K.H. Muhammad Yahya, disebut juga dan memiliki gelar keulamaan Syeikhina al-Alim al-Alamah al-Alim Billah Abuya K.H. Muhammad Yahya R.A. Lihat Muhammad Abubakar, Sekelumit Biografi Abuya K.H. Muhammad Yahya r.a. oleh K.H. Muhyiddin Abdulqodir alManafy (Darussurur), Youtube.com, Dipublikasikan pada 26 Mei 2017, Maqam Qomar Utama Cimahi, diakses pada 8 Mei 2018.

${ }^{16}$ Buya merupakan gelar ulama bagi tokoh agamawan, serupa dengan Kiai dan Ajengan yang merupakan sebutan ulama atau guru agama Islam di Jawa Barat. Lihat Dendy Sugono, Kamus Bahasa Indonesia (KBBI), (Jakarta: Pusat Bahasa Departemen Pendidikan Nasional, 2008), hlm. 24 dan 767.

${ }^{17}$ K.H. Muhammad Yahya merupakan Mursyid Thariqah Qodiriyyah wa Naqsabandiyyah (TQN). Lihat Buya Anom, Biografi Syeikhina..., hlm. 27. Istilah "tarekat" bersal dari kata "thariqah" dalam bahasa Arab, sebagai suatu istilah genetik atau turun temurun yang direpresentasikan seperti dan berarti sebuah "jalan", lebih lengkapnya sebuah jalan disini adalah "jalan menuju surga" dimana pelaku tarekat dalam melaksanakan amalan-amalan tarekatnya seringkali berusaha berkontemplasi penuh atas dirinya guna melampaui batas-batas kediriannya sebagai manusia demi mendekatkan dirinya ke sisi Allah SWT. Lihat Zamakhsyari Dhofier, Tradisi Pesantren, (Jakarta: LP3ES, 2011), hlm. 212.

${ }^{18}$ Buya Anom, Biografi Syeikhina Abuya ..., hlm. 5.

${ }^{19}$ Muhammad Samsudin, Laki-laki, 63 tahun, Kuncen Maqam Qomar, Cimahi: Maqam Qomar Utama, 22 Februari 2019.

${ }^{20}$ Shalahuddin dan Iskandar, 100 Tokoh Islam Paling Berpengaruh di Indonesia, (Jakarta: Intimedia Ciptanusantara, 2003), hlm. 197.

${ }^{21}$ M. Sulaeman Jazuli, Laki-laki, 47 tahun, Anak ke-15, Bandung: Pondok Pesantren Darussurur Pusat, 19 Mei 2018.

${ }^{22}$ Maulana Syarif Hidayatullah atau disebut juga Sunan Gunung Djati merupakan seorang wali yang berperan besar dalam proses Islamisasi di tanah Jawa, terutama di Jawa Barat pada abad ke-15 M. Beliau juga merupakan Sultan dari Cirebon, dan meninggal pada tahun 1428 M, makam beliau berada di Astana Gunung Sembung, Cirebon. Belia meninggalkan tiga 
2. Maulana Wilayatullah/Pangeran Jayakelana $(1486 \mathrm{M})^{23}$

3. Kyai Sirojuddin/Pangeran Panca Suryadibrata ${ }^{24}$

4. Kyai Zainal 'Abidin/Pangeran Suryadikusuma ${ }^{25}$

5. Kyai Asasuddin/Pangeran Suryadilaga ${ }^{26}$

6. Kyai 'Ishomuddin

7. Embah Kyai Anom

8. Ratna Sari

9. Asmara Sari

10. Daya Ningrum

11. Embah Keleye

12. Eyang Reti

13. Mama Enyang K.H. Mumammad Azhari

14. K.H. Muhammad Yahya/Buya Sepuh (1917M)

Nasab K.H. Muhammad Yahya dari garis Ayah yaitu K.H. Muhammad Azhari sampai pada Syarif Hidayatullah dan dengan demikian maka jika diteruskan lebih jauh lagi keatas akan sampai kepada Nabi Muhammad SAW., melalui putrinya yaitu Siti Fatimah az-Zahra, hal tersebut menjadi cukup menarik karena Syarif Hidayatullah atau Sunan Gunung Djati merupakan anak dari Syarif Mekah yaitu Sayyid Abdullah yang memiliki nasab sampai kepada Nabi Muhammad SAW.

Sejak kecil K.H. Muhammad Yahya sudah memiliki pribadi yang baik dan akhlak yang luhur, hal ini tidak terlepas dari peran kedua orangtua beliau yang mendidik dan membesarkan beliau dari kalangan keluarga dan lingkungan yang shaleh serta kultur keislaman yang tinggi. ${ }^{27}$ Sehingga, sejak kecil beliau dijaga oleh Allah SWT melalui didikan kedua orangtuanya dari pengaruh-pengaruh ajaran yang menyimpang, hingga beliau tetap terjaga baik dari sisi aqidah, keilmuan, akhlak, etika serta amaliah-amaliah

orang putra yang merupakan hasil perkawinannya dengan seorang putri dari Demak. Beliau juga mempunyai seorang putra dan seorang putri hasil perkawinanya dengan seorang selir. Lihat Thomas Stamford Raffles, The History of Java, (Yogyakarta: Penerbit Narasi, 2008), hlm. 491.

${ }^{23}$ Maulana Wilayatullah atau Pangeran Jayakelana merupakan anak dari Sunan Gunung Djati yang pertama dari istrinya yang bernama Nyimas Rara Jati. Lihat Sejarah Cirebon, Keturunan Sunan Gunung Djati dari Istri-istrinya, diakses melalui https://historyofcirebon.id/, pada tanggal 18 Juni 2019, pukul 21:11 WIB.

${ }^{24}$ Makamnya berada di Begong Kalisapu.

${ }^{25}$ Makamnya berada di Trusmi

${ }^{26}$ Makamnya berada di Trusmi.

27 Ayah beliau sendiri K.H. Muhammad Azhari merupakan seorang ulama yang terkenal keshalehannya yang mengamalkan ajaran-ajaran Nabi Muhammad SAW, sedang Ibunda beliau Hj. Khodijah merupakan seorang wanita shalihah. Lihat Buya Anom, Biografi Syeikhina Abuya..., hlm. 5. 
kesehariannya, ${ }^{28}$ hal ini pula didukung dengan begitu besarnya minat dan ketekunan beliau dalam mempelajari ilmu agama sejak kecil, yang menjadi pondasi utama bagi pemahaman religiusitas dan spiritualitas beliau, hal tersebut termanifestasikan dari begitu banyaknya guru-guru agama yang menyertai dan mewarnai perjalanan intelektualitas beliau. ${ }^{29}$

Sebagai seorang ulama besar, silsilah (nasab/genelogi) beliau tentu sangat penting bagi umat, keturunan pun menjadi suatu yang penting pula, terlebih dalam usaha mewariskan keilmuan, cita-cita, dan perjuangan dalam berdakwah. Menjelang dewasa, K.H. Muhammad Yahya menikah dengan Hj. Umi Hafshah. ${ }^{30}$ Istri-istri beliau, nama-namanya terkutip dalam nadhom yang beliau tulis, dimana secara keseluruhan ada tiga istri, dalam Nadhom Wasiat al-Habib Abdullah al-Hadad, dimana di akhir tulisan nadhomnya, K.H. Muhammad Yahya turut menuturkan nasihatnya kepada keluarganya, tidak terkeculai kepada bojo atau istrinya, ${ }^{31}$ yaitu Ma Unah $\left(\mathrm{Hj}\right.$. Hunah) ${ }^{32}$, Ma Iting

${ }^{28}$ KH. Muhyiddin Abdulqodi al-Manafy berkata bahwa, "Shahibul haol K.H. Muhammad Yahya adalah orang yang dijaga oleh allah dari kecilnya, dari berbagai pengaruh-pengaruh yang menyimpang daripada ajaran-ajaran shalaf, baik dari sisi aqidah, keilmuan, pemikiran, akhlak dan etika, dan amaliah-amaliah beliau." Lihat Muhammad Abubakar, Sekelumit Biografi Abuya K.H. Muhammad Yahya r.a. oleh K.H. Muhyiddin Abdulqodir al-Manafy (Darussurur), Youtube.com, Dipublikasikan pada 26 Mei 2017, Maqam Qomar Utama Cimahi, diakses pada 8 Mei 2018.

${ }^{29}$ M. Sulaeman Jazuli, Laki-laki, 47 tahun, Anak ke-15, Bandung: Pondok Pesantren Darussurur Pusat, 19 Mei 2018.

${ }^{30}$ Dari Hj. Umi Hafshah, K.H. Muhammad Yahya dikaruniai empat orang keturunan, yaitu K.H.Muhammad Sahlan, Hj. Minah, K.H. Abdul Wahab dan K.H. Abu Hamid. Lihat Jalaluddin Sayuthi, Laki-laki, 65 tahun, Menantu dan Pengurus SD, SMP, SMK Plus Darussurur, Cimahi: Mushola SMP Plus Darussurur, 23 Juni 2019. Lihat pula Muhammad Samsudin, Laki-laki, 63 tahun, Kuncen Maqam Qomar, Cimahi: Maqam Qomar Utama, 22 Februari 2019.

31 K.H. Muhammad Yahya tercatat telah beberapa kali menikah. Lihat Lihat Ibu Siti, Perempuan, 51 tahun, masyarakat sekaligus jamaah dari K.H. Muhammad Yahya, Bandung: Kediaman Beliau, 22 Januari 2019.

32 Dari Hj. Umi Hunah, K.H. Muhammad Yahya dikaruniai dua belas putra dan putri, masing-masing empat orang putra dan delapan orang putri, yaitu Hj. Sofiah, K.H. Abu Tamam, Hj. Aisyah, Hj. Rukoyah, Hj. Rumaisoh, Hj. Aminah, Umi Hani, Hj. Zainab, Hj. Khodijah, K.H. Sulaiman Jazuli, K.H. Junaedi, K.H. Abu Bakar. Lihat Jalaluddin Sayuthi, Laki-laki, 65 tahun, Menantu dan Pengurus SD, SMP, SMK Plus Darussurur, Cimahi: Mushola SMP Plus Darussurur, 23 Juni 2019. Lihat pula Muhammad Samsudin, Laki-laki, 63 tahun, Kuncen Maqam Qomar, Cimahi: Maqam Qomar Utama, 22 Februari 2019. 
(Hj. Hafshah), Hj. Umi Satriah, ${ }^{33}$ sebagaimana yang terturut dalam nadhomnya. ${ }^{34}$

“...Karunia nu agung medal ieu nasihat, anu jadi wasiat ti Buya ka baraya. Ka sakabeh turunan anak, minantu, bojo, murid-murid, jeung sobat nu bageur nu satia. Oge ngiring wasiat Ma Unah jeung Ma Iting, Hajah Hunah Satriah, ka anak ka baraya..." (Halaman 73 kitab Mazmu fi alNadhomati al-Arobiyah Darussurur)

Istri-istri beliau tersebut tentunya turut pula mendampingi dan memberi dukungan bagi beliau dalam sepanjang riwayat dakwah Islamiahnya, dan anak-anak keturunannya menjadi pelanjut eksistensi beliau dalam mengarungi aktivitas dakwahnya.

Keseharian beliau diwarnai untuk mengajar dan berdakwah, dimana beliau biasanya tidur terkadang jam 10.00 atau 11.00 malam, dan bangun pada jam 02.00 malam, setelah bangun kegiatan beliau adalah membaca Aurod dan al-Qur'an hingga masuk waktu subuh, dan selepas subuh dilanjut lagi dengan kegiatan yang sama hingga jam 10.00 pagi. Kemudian beliau menyediakan waktu untuk menerima tamu hingga waktu dzuhur, dan ba'da dzuhur beliau mengajar hingga masuk waktu ashar, kemudian dilanjut mengaji sampai maghrib, dan kemudian ba'da maghrib, beliau wiridan hingga isya, dan selepas isya, beliau lanjut mengajar hingga jam 10.00 malam..$^{35}$

Sebagai seorang tokoh panutan umat K.H. Muhammad Yahya merupakan seorang ulama yang kharismatik dan memiliki kepribadian, akhlak serta budi pekerti yang luhur, akhlak dan perangai beliau merupakan cerminan dari akhlak dan perangai Rasulullah SAW. Beliau memiliki sifat wara', menghormati tamu, menghargai sesama, dermawan dan selalu rendah hati kepada setiap orang tanpa memandang siapa dan latarbelakangnya apa. Setiap yang datang menemui beliau, maka akan selalu mendapatkan faidah, nasihat dan pesan yang menenangkan hati dan bijak, sehingga beliau sangat disegani dan dikagumi oleh siapapun yang bertemu dan mengenal beliau. ${ }^{36}$

Selain itu beliau merupakan ulama yang senantiasa istiqamah dengan berbagai amalan, dimana beliau tidak pernah lepas dan meninggalkan kewajiban beliau dalam beribadah dan melaksanakan amalan-amalan beliau, beliau senantiasa konsisten dengan setiap amalannya, hal ini tidak terlepas dari

${ }^{33}$ Dari Hj. Umi Satriah, K.H. Muhammad Yahya dikaruniai satu orang putri yaitu $\mathrm{Hj}$. Mauludah. Lihat Jalaluddin Sayuthi, Laki-laki, 65 tahun, Menantu dan Pengurus SD, SMP, SMK Plus Darussurur, Cimahi: Mushola SMP Plus Darussurur, 23 Juni 2019. Lihat pula Muhammad Samsudin, Laki-laki, 63 tahun, Kuncen Maqam Qomar, Cimahi: Maqam Qomar Utama, 22 Februari 2019.

${ }^{34}$ Muhammad Abd al-Qadir bin K.H. Abdullah Qasim Shaleh, Mazmu fi al-Nadhomati alArobiyah Darussurur, (Bandung: Ma'had Darussurur), hlm. 73.

35 M. Sulaeman Jazuli, Laki-laki, 47 tahun, Anak ke-15, Bandung: Pondok Pesantren Darussurur Pusat, 19 Mei 2018.

${ }^{36}$ Buya Anom, Biografi Syeikhina Abuya ..., hlm. 9-12. 
sikap wara dan takdzim beliau kepada guru-gurunya, beliau selalu menghormati. ${ }^{37}$

Sebagai seorang ulama besar K.H. Muhammad Yahya memiliki kedisiplinan dan keistiqamahan yang tinggi dalam melaksanakan amalanamalan yang diperintahkan oleh agama, serta yang beliau laksanakan mengikuti ajaran-ajaran sanad keilmuan guru-gurunya. Salah satu amalan beliau yang secara berkesinambungan tidak pernah ditinggalkan adalah dimana beliau selalu mewajibkan dirinya untuk melaksanakan shalat secara berjama'ah di mesjid, dan hal ini tidak pernah beliau tinggalkan. Bahkan, beliau sendiri selalu menekankan kepada semua jama'ahnya untuk senantiasa shalat berjama'ah, karena menurutnya shalat berjama'ah merupakan anjuran Rasulullah SAW., bahkan sangat ditekankan oleh Rasulullah SAW., kepada umatnya. $^{38}$

K.H. Muhammad Yahya sendiri, beliau dikenal sebagai ahli dzikir, membaca maulid ${ }^{39}$ dan qashidah mudhoriyah. ${ }^{40}$ Dalam kesehariannya beliau tidak pernah lepas dari membaca al-Qur'an dan wirid-wirid (kumpulan dzikir) yang bersumber dari al-Qur'an dan sunah-sunah Nabi Muhammad SAW, bahkan amaliah-amaliah beliau tersebut, beliau laksanakan dan tidak pernah ditinggalkan meski ketika dalam keadaan bepergian maupun dalam keadaan sakit hingga menjelang detik-detik kewafatannya. ${ }^{41}$

Selain dzikir, amalan dan ibadah badaniyah yang senantiasa beliau amalkan adalah shalat malam (tahajud) yang terdiri dari Shalat Hajat, Shalat Witir 11 Raka'at, dan Shalat Tasbih 4 Raka'at. Beliau juga mengerjakan shalat-shalat lainnya, yang kemudian setelah selesai dilanjutkan dengan membaca aurod-aurod ${ }^{42}$ dan do'a-do'a yang dilaksanakan setiap sepertiga malam sampai menjelang subuh, beliau pula pernah mengatakan bahwa "Apabila aku belum melaksanakan amalan tersebut maka aku tidak bisa tidur". ${ }^{43}$

Amalan-amalan beliau lainnya yang senantiasa dilakukan adalah berziarah kepada kedua orangtua dan guru-gurunya yang sudah meninggal, dalam amalan ini, beliau secara rutin melaksanakan dalam tempo waktu

\footnotetext{
${ }^{37}$ Buya Anom, Biografi Syeikhina Abuya..., hlm. 12-26.

${ }^{38}$ Buya Anom, Biografi Syeikhina Abuya..., hlm. 13.

${ }^{39}$ Pembacaan maulid identik dengan membacakan maulid al-Barzanji, yang didalamnya berisikan do'a, puji-pujian, shalawat, dan riwayat nabi Muhammad SAW. Lihat Marlyn Andryyanti, Makna Maulid Nabi Muhammad SAW, (UIN Makasar: Skripsi Fakultas Dakwah dan Komunikasi, 2017), hlm. 4.

${ }^{40}$ Qashidah Mudhoriyah merupakan Shalawat yang berasal dari syair karya Imam alBusyiri.

${ }^{41}$ Buya Anom, Biografi Syeikhina Abuya ..., hlm. 13-14.

42 Aurod dikenal juga dengan istilah wirid, dimana aurod merupakan amalan-amalan spiritual yang dikerjakan oleh seorang shaleh.

${ }^{43}$ Buya Anom, Biografi Syeikhina Abuya..., hlm. 14-15.
} 
minimal setiap satu minggu sekali, bahkan hal tersebut dilaksanakan beliau meski dalam keadaan sedang sakit, beliau pula senantiasa merutinkan berziarah kepada guru-gurunya walaupun harus memakai kursi roda. ${ }^{44}$

\section{Riwayat Pendidikan dan Genelogi Keilmuan K.H. Muhammad Yahya}

Jaringan kekerabaran dan genelogi keilmuan Islam di Indonesia terhimpun dan terhubung melalui pondok pesantren, dimana transmisi keilmuan antara kyai dan murid menghasilkan suatu jaringan dan genelogi baik ukhwah keislaman maupun intelektualitas keagamaan. Sejak tahun 1900an di Cimahi telah berdiri beberapa pondok pesantren yang dibangun oleh para kyai dan ulama setempat, seperti K.H. Muhammad Kurdi, yang membangun Pondok Pesantren Cibabat pada 1932, yang segenerasi dengan ulama-ulama besar lainnya seperti K.H. Zarkasih (Ponpes Cibaduyut), Ajengan Dimyati (Ponpes Sukamiskin), dan Mama Ajengan Cibitung Cililin. Selain Pondok Pesantren Cibabat, berdiri pula Pesantren-pesantren lainnya, seperti Pesantren Cibeureum Kidul (Mbah Mukodar), Pesantren At-Taqwa (H. Ahmad Syafei), Pesantren al-Musyaadah (K.H. Asep Saefudin) ${ }^{45}$ dan Pesantren Darussurur (K.H. Muhammad Yahya).

Lingkungan pesantren selain dibangun karena semangat dakwah, juga dibangun secara biologis lewat kaitan kekerabatan dan pernikahan diantara keluarga para kyai, hal itu terjadi terhadap pondok pesantren yang ada di wilayah Cimahi dan sekitarnya, dimana hampir semua ulama dan pesantren di Cimahi dan sekitarnya bahkan menyeberang sampai ke beberapa pesantren di Garut, Tasikmalaya, Cianjur, Ciamis, hingga Cirebon mempunyai hubungan kekeluargaan satu sama lainnya. ${ }^{46}$

Riwayat pendidikan dan genelogi keilmuan K.H. Muhammad Yahya terkonstruk dari lingkungan beliau dilahirkan dan dibesarkan, dimana beliau di didik dari kalangan keluarga yang shaleh dengan dilingkupi suasana yang religius, riwayat pendidikan agama beliau dimulai secara langsung dibawah bimbingan Ayahnya yang juga merupakan seorang ulama, yaitu K.H. Muhammad Azhari dan Ibundanya, yaitu $\mathrm{Hj}$. Khodijah yang menjadi tempat belajar pertama atau al-Madrasah al-Uula ${ }^{47}$ beliau hidup dan dibesarkan dalam lingkungan yang dipenuhi nilai-nilai luhur dengan berlandaskan spiritualitas ajaran-ajaran Baginda Rasulullah SAW. ${ }^{48}$

\footnotetext{
${ }^{44}$ Buya Anom, Biografi Syeikhina Abuya..., hlm. 15.

${ }^{45}$ Nina Herliana Lubis, Sejarah Kota Cimahi, (Pemerintah Kota Cimahi, 2015), hlm. 220226.

${ }^{46}$ Nina Herliana Lubis, Sejarah Kota Cimahi..., hlm. 224.

${ }^{47}$ al-Ummu Madrasah al-Uula, artinya "Ibu adalah tempat belajar pertama", bagi seorang anak dalam keluarga, dimana kedua orang tua menjadi pondasi bagi pendidikan awal anaknya. Lihat Buya Anom, Biografi Syeikhina Abuya..., hlm. 5.

${ }^{48}$ Buya Anom, Biografi Syeikhina Abuya..., hlm. 5-6.
} 
Dari semenjak kecil beliau telah memiliki minat dan ketekunan yang besar dalam mempelajari dan menekuni ilmu agama, serta mengkhatamkan alQur'an dan mengkaji beberapa disiplin ilmu kepada guru-gurunya. Seiring bertambahnya usia, beliau tidak lantas puas dengan hanya berpangku tangan pada pendidikan dan ilmu-ilmu yang diajarkan oleh kedua orang tuanya, bahkan beliau semakin giat dan aktif dalam menuntut ilmu, secara formal pendidikan beliau dimulai di SR (Sekolah Rakyat) yang saat itu hanya sampai pada kelas 3 saja, kemudian beliau memutuskan untuk mulai nyantren atau belajar di pesantren, tepatnya di Madrasah al-Mu'awanah (Cianjur). ${ }^{49}$

Setelah selesai menimba ilmu di Madrasah al-Mu'awanah beliau kemudian menimba ilmu-ilmu syariat kepada guru-guru beliau diiringi dengan mengkaji beberapa disiplin ilmu, bahkan seiring bertambahnya usia, beliau semakin giat dan aktif dalam menuntut ilmu, serta menyempatkan waktu khusus untuk bertabarruq ke berbagai pesantren dan beristifadah (mengambil faidah) serta menimba ilmu dari para ulama dan aulia yang berada disekitar tempat tinggalnya (di dalam maupun di luar Bandung) untuk menuntut ilmu dan mengambil sanad serta ijazah mereka. ${ }^{50}$ Bahka, beliau rela menempuh jarak yang jauh dengan berjalan kaki demi menemui gurunya yang berada di Pondok Pesantren Cibabat (Raden K.H. Muhammad Kurdi dan anaknya K.H. Zaini Dahlan atau Abuya Elon).

Bahkan, K.H. Muhammad Yahya memiliki teman akrab saat beliau menimba ilmu, yang juga merupakan seorang ulama besar pula di Jawa Barat bernama K.H. Ahmad Toha Mustawi (Apa Oha atau Apa Bojong) ${ }^{51}$ yang merupakan ayah dari Abuya K.H. Muhammad Muhyiddin al-Manafi, yang juga merupakan murid dari K.H. Muhammad Yahya, sekaligus pimpinan Pondok Pesantren dan Majelis Ta'lim Asy-Syifaa Wal Mahmudiyyah di Sumedang. ${ }^{52}$

Diantara ulama yang menjadi guru beliau salah satunya adalah K.H. Ahmad Zarkasyi (Utama) padanya beliau mempelajari ilmu-ilmu syari'at dan juga kepada K.H. Muhammad Zarkasyi atau yang lebih banyak dikenal

\footnotetext{
${ }^{49}$ Pondok Pesantren al-Mu'awanah merupakan pondok pesantren yang didirikan oleh K.H. Muhammad Ghozali bin Hannan dan Hj. Maemunah (istrinya) pada tahun 1949 di Cianjur. Lihat Pondpes al-Mu'awanah, 2012, Pesantren al-Mu'awanah-Cianjur Selatan, diakses melalui https://pondpesalmuawanah.blogspot.com/, diakses pada 12/2/2019 pukul 14:36 WIB.

${ }^{50}$ Majalah al-Kisah, Kisah Ulama Buya K.H. M. Yahya Bandung: Ulama Amilin Bukan Ulama “Ambilin”, (Jakarta:PT. Dian Rakyat Jakarta, Edisi 6 tahun 2013), hlm. 56.

${ }^{51}$ Muhammad Samsudin, Laki-laki, 63 tahun, Kuncen Maqam Qomar, Cimahi: Maqam Qomar Utama, 22 Februari 2019.

${ }^{52}$ Pondok Pesantren dan Majelis Ta'lim As-Syifaa wal Mahmudiyyah juga pernah dijadikan bahan penelitian doctoral (Thesis) oleh Deden Sumpena dengan judul Kohesivitas Keagamaan Jamaah Pengajian Majlis Ta'lim Asy-Syifaa Wal Mahmuudiyyah Tahun 2014 M, di Universitas Sunan Gunung Djati Bandung.
} 
dengan Mama Cibaduyut atau Mama Cihapit,${ }^{53}$ darinya beliau belajar dan mengambil ijazah serta Aurad ${ }^{54}$ khusus (amalan-amalan). ${ }^{55}$

Kemudian, guru-guru beliau yang lain, antara lain adalah Mama Eyang Cibabat atau Raden K.H. Muhammad Kurdi, yang merupakan seorang ulama besar nan kharismatik pendiri Pondok Pesantren Cibabat, ${ }^{56}$ selain itu beliau juga berguru pada anak dari K.H. Muhammad Kurdi yaitu K.H. Muhammad Hasan Imam Rafi atau Buya Iping (yang menjadi guru sekaligus mertua beliau) dan K.H. Ahmad Zaini Dahlan atau Buya Elon, dimana darinya beliau nyantren dan belajar ilmu agama bahkan hingga mendapatkan gelar Kyai. ${ }^{57}$

Selanjutnya K.H. Muhammad Yahya juga menimba ilmu dan juga mengambil ijazah Thariqah Qadiriyyah wa Naqsabandiyyah (TQN) dari Cirebon yaitu kepada K.H. Zaenal Abidin, yang merupakan anak dari Syaikh Tolhah Cirebon yang merupakan seorang tokoh ulama dan mursyid pengembang Thariqah Qodiriyah wa Naqsabandiyah di Cirebon dan wilayah Timur Jawa Barat, beliau juga merupakan murid dari Syaikh Akhmad Khatib Sambas seangkatan dengan Syaikh Abdul Karim Banten dan Syaikh Holil Madura yang mempelajari ilmu Tasawuf dan Thariqah dari Syaikh Akhmad Khatib Sambas di Mekah. ${ }^{58}$

1. Syaikh Akhmad Khatib Sambas (Guru Syaikh Tolhah) Tahun 1803$1875 \mathrm{M}$

2. Syaikh Tolhah (Ayah K.H. Zaenal Abidin) Tahun 1825-1935M dimakamkan di Gunung Djati.

3. K.H. Zaenal 'Abidin/Mama Zen (Guru K.H. Muhammad Yahya) dimakamkan di Trusmi.

4. K.H. Muhammad Yahya

Maka dapat disimpulkan bahwa K.H. Zaenal Abidin memiliki nasab Thariqah Qadiriyah wa Naqsabandiyah sampai pada Syaikh Akhmad Khatib Sambas

${ }^{53}$ K.H. Muhammad Zarkasyi merupakan pendiri Pondok Pesantren ar-Rasyid yang tercatat sebagai pondok pesantren tertua di Kota Bandung. Lihat MuslimMN, 2014, K.H. Raden Muhammad Zarkasyi (Mama Eyang Cibaduyut), diakses melalui https://pustakamuhibbin.blogspot.com/, pada 13/02/2019, pukul 13:50 WIB.

${ }^{54}$ Dalam kamus Tasawuf, Aurad adalah kata jamak dari Wirid, yang merupakan bacaan zikir, do'a, dan ibadah sunah lainnya yang pengamalannya dibiasakan pada waktu-waktu yang telah ditentukan. Lihat Valeria Pramita, Resume Tasawuf III: Wirid-wirid Para Sufi, (Padang: IAIN Imam Bonjol, 2014), hlm. 2.

${ }^{55}$ Majalah al-Kisah, Kisah Ulama ..., hlm. 56.

${ }^{56}$ K.H. Muhammad Kurdi merupakan keturunan ke-5 dari Syaikh Raden Dalem Haji Abdul Manaf atau Eyang Dalem Mahmud yang merupakan sesepuh ulama Bandung yang tentunya memiliki pengaruh besar pada masanya dalam penyebaran dan pengembangan dakwah Islam di Kota Bandung. Lihat Ari Anjar R, Biografi Sejarah dan Pemikiran K.H. Muhammad Kurdi Mama Cibabat Cimahi (1839-1954), (UIN Bandung: Historia Madania), hlm. 72 dan 74.

${ }^{57}$ Buya Anom, Biografi Syeikhina Abuya..., hlm. 22.

58 Astana Gunung Djati Cirebon, Sejarah Syaikh Tolhah, diakses melalui http://tqncirebon.blogspot.com/, pada tanggal 13/2/2019, pukul 19:04 WIB. 
yang sanadnya sampai kepada Nabi Muhammad SAW melalui ayahnya Syaikh Tolhah yang darinya K.H. Muhammad Yahya belajar ilmu-ilmu syari'at dan mendapat amalan-amalan wirid (kumpulan dzikir), ${ }^{59}$ bahkan beliau hanya dalam waktu satu malam saja sudah mampu menguasai ilmu Thariqah hingga membawa beliau diangkat langsung oleh gurunya untuk menjadi seorang guru mursyid bagi Thariqah Qadiriyah wa Naqsabandiyah (TQN). ${ }^{60}$

Selain medapatkan ijazah dan diangkat menjadi mursyid Thariqah Qadiriyah wa Naqsabandiyah oleh K.H. Zaenal Abidin (Cirebon), K.H. Muhammad Yahya juga belajar dan mengambil Ijazah Thariqah 'Alawiyah dari al-Imam Alhafidz Almusnid Alqutub al-Habib Abdullah bin Abdul Qadir bin al-Faqih di Malang, Jawa Timur. ${ }^{61}$ Kemudian beliau pula belajar dan menimba ilmu pada al-Imam Alqutub al-Habib Ali bin Husain al-Attos di Jakarta, padanya beliau mengambil ijazah Aurod Assadatul 'Alawiyyin wa Khirqotus Sufiyyah (sejenis kain sufi) yang menjadi simbol betapa dekatnya hubungan antara guru dan murid diantara mereka yang dipenuhi ke ta'dziman selama proses transmisi keilmuan terjadi. ${ }^{62}$

Selain guru-guru dan para ulama nusantara yang beliau ambil ilmu dan ijazahnya, K.H. Muhammad Yahya juga sempat mengambil ijazah kitab-kitab hadist dan do'a-do'a dari guru beliau yaitu al-Muhaddist Assayid Alwi bin Abbas al-Malik ketika beliau pergi melaksanakan ibadah haji di Mekkah. ${ }^{63}$ Beliau merupakan seorang Habaib kelahiran Mekkah, dari sanad ayahnya yaitu Idris al-Azhar bin Idris al-Akbar bin 'Abdullah al-Kamil bin Hasan alMutsanna bin Hasan. ${ }^{64}$

${ }^{59}$ Ustadz Irfan, Laki-laki, 34 tahun, Cucu K.H. Muhammad Yahya, Bandung: Pondok Pesantren Darussurur 27, 23 Februari 2019.

${ }^{60}$ Rekaman Haol Buya Yahya yang ke IX, Pengangkatan Abuya Abuya K.H. Muhammad Yahya sebagai Mursyid Tariqah Qadiriyah wa Naqsabandiyah oleh K.H. Thahir, Rekaman Tanggal 13 Mei 2018.

${ }^{61}$ Al-Habib Abdullah beliau merupakan seorang ulama ahli hadits yang masyhur, dan pimpinan Pondok Pesantren Darul Hadits al-Faqihiyyah Ahlus Sunnah wal Jamaah (1945) di Kota Malang, Jawa Timur. Lihat Abdkadiralhamid, 2013, Biografi Habib Abdullah bin Abdul Qadir Bil Faqih al Alawi, Malang, Jawa Timur, diakses melalui http://ahlulbaitrasulullah.blogspot.com/, pada tanggal 13/2/2019, pukul 19:23 WIB.

${ }^{62}$ Muhammad Abd al-Qadir bin K.H. Abdullah Qasim Shaleh, Mazmu fi al-Nadhomati alArobiyah Darussurur, (Bandung: Ma'had Darussurur), hlm. bagian akhir penutup kitab.

${ }^{63}$ Muhammad Abd al-Qadir bin K.H. Abdullah Qasim Shaleh, Mazmu fi al-Nadhomati alArobiyah Darussurur, (Bandung: Ma'had Darussurur), hlm. bagian akhir penutup kitab.

${ }^{64}$ Assayid Alwi juga merupakan seorang ulama besar yang mengajar berbagai ilmu Islam turath di Masjidil Haram, dan memiliki ratusan murid dari penjuru dunia, majelis beliau dikenal dengan Majelis Dalailul Khairat dan Majelis Burdah. Lihat Dhimas Ragil, Biografi Sayyid Abbas bin Alwi al-Maliki, diakses melalui http://syukronmaba.blogspot.com/, pada tanggal 13/2/2019, pukul 19:54 WIB. Lihat juga, Ensiklopedia NU, Sayyid Alwi bin Abbas alMaliki, diakses melalui http://wiki.laduni.id/, pada tanggal 13/2/2019, pukul 19:56 WIB. 
Bila dilihat dari perjalanan riwayat pendidikan dan genelogi keilmuan beliau, kita dapat melihat betapa mempuni dan betapa luhur ilmu yang beliau miliki, dengan berbagai guru, dan disiplin ilmu yang beliau tekuni, terlebih dengan beberapa ijazah Thariqah dan ilmu Syariat yang beliau dapatkan, serta gelar Mursyid yang beliau dapatkan pula, baik sebagai Mursyid Thariqah Qadiriyyah wan Naqsabandiyyah dan Thariqah 'Alawiyah, serta menimba ilmu pula kepada guru internasional, beliau membuktikan diri untuk menjadi seorang ulama dan guru besar dikemudian hari.

\section{Aktivitas Dakwah K.H. Muhammad Yahya di Cimahi}

Dakwah menjadi metode yang cukup efektif dalam menyebarluaskan semangat Islamisasi dan pengembangan Islam, diluar dari referensi yang diberikan al-Qur'an, dakwah menjadi hal yang paling vital dalam menyongsong perkembangan Islam di suatu wilayah. Kata dakwah sendiri berasal dari kata $d a^{\prime} a a, y a d^{\prime} u$, da'watan yang artinya menyeru, mengajak, atau memanggil. Dimana dakwah merupakan sebuah sikap dan usaha yang dilakukan untuk mengajak dan menyeru manusia kearah yang lebih baik, terutama kepada ajaran Islam. ${ }^{65} \mathrm{Hal}$ ini sejalan menurut pendapat Mawardi MS (2008), bahwa dakwah adalah menyampaikan ajaran-ajaran Islam atau menyeru masyarakat kejalan yang lurus agar sesuai dengan ajaran agama Islam. ${ }^{66}$ Selain itu, dakwah juga berfungsi untuk menyeru dan menyampaikan kepada orang-perorangan maupun umat mengenai konsep ajaran Islam prihal pandangan dan tujuan hidup manusia yang secara garis bersar meliputi apa yang dinamakan amar ma'ruf nahyi munkar (menyeru pada kebaikan dan mencegah keburukan), dengan berbagai macam media dan cara. ${ }^{67}$ Sebagaimana yang terdapat dalam QS. Ali Imron ayat 104, yang menjadi landasan dalil dalam seruan dakwah.

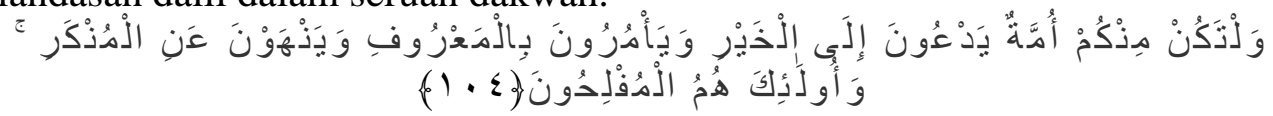

Artinya: "Dan hendaklah ada diantara kamu segolongan orang yang menyeru (berbuat) yang makruh dan mencegah dari yang mungkar. Dan mereka itulah orang-orang yang beruntung." (Qs. Ali Imron: 104)

Cara (Metode) dan media dakwah secara eksplisit juga dijelaskan dalam al-Qur'an, tepatnya dalam QS. An-Nahl ayat 125, dimana cara berdakwah harus berlandaskan pada keikhlasan dan dilakukan dengan caracara yang baik.

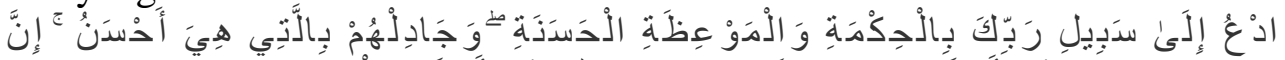

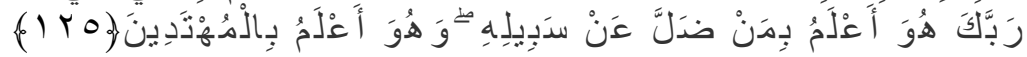

\footnotetext{
${ }^{65}$ M. Syafa'at Habib, Buku Pedoman Dakwah, (Jakarta: Wijaya, 1992), hlm. 93.

${ }^{66}$ Mawardi MS, Sikologi Dakwah: Kajian Teori Sosiologi, al-Qur'an, dan al-Hadits, (Ponorogo: Uwais Inspirasi Indonesia, 2008), hlm. 1.

${ }^{67}$ M. Natsir, Fungsi Dakwah Islam dalam Rangka Perjuangan, (Jakarta: Media Dakwah, 1979), hlm. 7.
} 
Artinya: "Serulah (manusia) kepada jalan Tuhan-mu dengan hikmah dan pelajaran yang baik dan bantahlah mereka dengan cara yang baik. Sesungguhnya Tuhan-mu dialah yang lebih mengetahui tentang siapa yang tersesat dari jalan-Nya dan Dialah yang lebih mengetahui orang-orang yang mendapat petunjuk." (Qs. An-Nahl: 125)

Metode dakwah secara garis besar yang memenuhi prinsip-prinsip pada dalil Qs. An-Nahl ayat 125 ada tiga pokok, yaitu: Pertama, Dakwah Bil Hikmah yaitu dakwah dengan cara memberikan contoh yang baik. Kedua, Dakwah Mau'izatul Hasanah yaitu dakwah dengan cara memberikan nasehatnasehat yang baik yang berkaitan dengan ajaran-ajaran Islam. Ketiga, Dakwah Mujadalah Billati Hiya Ahsan, yaitu berdakwah dengan cara bertukar pikiran (diskusi) dengan cara-cara yang baik.

Dalam proses dan aktivitas dakwahnya, para ulama menggunakan beberapa media dalam berdakwah yang terbagi kedalam beberapa macam, secara umum media yang digunakan dalam aktivitas dakwah dapat diklasifikasikan dalam tiga kategori, yaitu: Pertama, Dakwah bi al-lisan, yaitu merupakan media dakwah dengan media penyampaian informasi dan pesan dakwah melalui lisan, dapat berupa ceramah, khutbah, dll. Kedua, Dakwah bi al-qalam, yaitu merupakan media dakwah dengan media penyampaian informasi dan pesan dakwah melalui tulisan, seperti berupa buku, majalah, dll. Ketiga, Dakwah bi al-hal, yaitu dakwah melalui perbuatan nyata atau contoh akhlak yang baik yang sesuai dengan ajaran Islam. ${ }^{68}$

Dalam melaksanakan dakwahnya K.H. Muhammad Yahya lebih banyak menggunakan cara praktis atau dakwah bil hal dengan cara terbuka, dan materi dakwahnya pun cukup luas menyangkut ajaran Islam secara keseluruhan yang mampu diterima oleh berbagai kalangan di masyarkat. ${ }^{69}$ K.H. Muhammad Yahya senantiasa menggunakan berbagai media dan cara dalam berdakwah, baik lisan berupa ceramah, tulisan berupa menulis bebera Nadhom, dan perbuatan berupa langkah mengajar dengan membangun Institusi Pendidikan Islam Trandisional (Pesantren). Sehingga bila dijelaskan secara menyeluruh, aktivitas dakwah KH. Muhammad Yahya meliputi dakwah melalui Pendidikan (Mengajar), Ceramah Keagamaan, Thariqah, bahkan Tulisan.

Dakwah Melalui Lembaga Pendidikan (1947-2009), lembaga pendidikan merupakan sarana yang memiliki posisi cukup penting dalam membangun intelektualitas generasi muda, selain itu, pendidikan juga menjadi aspek terpenting guna terselenggaranya geliat dakwah secara masif dan terpusat, dan K.H. Muhammad Yahya melihat itu dalam perjalanan

${ }^{68}$ Wardi Bachtiar, Metodologi Penelitian Ilmu Dakwah, (Jakarta: Logos Wahan Ilmu, 1997), hlm. 34.

${ }^{69}$ Jalaluddin Sayuthi, Laki-laki, 65 tahun, Menantu dan Pengurus SD, SMP, SMK Plus Darussurur, Cimahi: Mushola SMP Plus Darussurur, 23 Juni 2019. 
dakwahnya. Dimana beliau bersama kerabat dan keturunannya mendidik dan mengajarkan ilmu-ilmu keislaman kepada santri-santrinya di Pondok Pesantren Darussurur yang beliau bangun pada tahun $1947,{ }^{70}$ sistem pengajaran yang diterapkan serupa dengan pesantren-pesantren salaf pada umumnya yang menerapkan sistem sorogan,${ }^{71}$ bandongan,${ }^{72}$ dan hafalan di setiap kegiatan pengajarannya. ${ }^{73}$ Kitab yang diajarkanpun merupakan kitabkitab kuning pada umumnya, namun kitab pokok yang diajarkan adalah kitab Tafsir Jalalain dan Ihya Ulumuddin yang dipelajari setiap pagi dan sore. Sedangkan santri-santri yang belajar di Pesantren Darussurur berasal dari berbagai daerah baik dalam maupun luar Cimahi, seperti Bandung, Jakarta, Garut, Cianjur, dan Sumedang, yang pada umumnya lebih banyak merupakan santri kalong, pada awal pendiriannya jumlah santri hanya sebanyak 20 orang, kemudian terus berkembang hingga tahun 1985 mencapai 200 orang, baik santri kalong maupun santri mukim. ${ }^{74}$

Pondok pesantren yang beliau dirikan terus bertambah anak cabangnya, mulai tahun 1976 didirikan cabang pondok pesantren baru di Desa Panyaweuyan, Cimahi, disusul tahun 1985 di Desa Cibodas dan Lagadar, hingga tahun 1985 sudah ada 5 cabang pondok pesantren, dan terus berkembang sampai pada tahun 2000 telah ada sebanyak 9 cabang pondok pesantren, ${ }^{75}$ dengan diikuti pembangunan lembaga pendidikan formal berupa

${ }^{70}$ M. Sulaeman Jazuli, Laki-laki, 47 tahun, Anak ke-15, Bandung: Pondok Pesantren Darussurur Pusat, 19 Mei 2018.

${ }^{71}$ Sorogan berasal dari bahasa Jawa, yaitu dari kata "Sorog" yang artinya menyodorkan, dimana pada metode ini para Santri dapat menyodorkan materi yang ingin dipelajarinya, sehingga mendapatkan bimbingan secara individual dan khusus dari Kyai di Pesantren. Lihat Hafidz Muftisany, Sorogan dan Bandongan Metode Khas Pesantren, diakses melalui https://republika.co.id/, pada tanggal 23 Juni 2019, Pukul 10.11 WIB.

72 Balaghan hampir sama dengan Bandongan dalam bahasa Sunda, yaitu dari kata "Bandungan" yang artinya memperhatikan secara seksama atau menyimak, dimana pada metode ini para Santri akan belajar dengan menyimak penjelasan Kyai secara kolektif. Lihat Hafidz Muftisany, Sorogan dan Bandongan Metode Khas Pesantren, diakses melalui https://republika.co.id/, pada tanggal 23 Juni 2019, Pukul 10.11 WIB.

${ }^{73}$ Jalaluddin Sayuthi, Laki-laki, 65 tahun, Menantu dan Pengurus SD, SMP, SMK Plus Darussurur, Cimahi: Mushola SMP Plus Darussurur, 23 Juni 2019. Lihat juga Zamakhsyari Dhofier, Tradisi Pesantren ..., hlm. 54.

${ }^{74}$ M. Sulaeman Jazuli, Laki-laki, 47 tahun, Anak ke-15, Bandung: Pondok Pesantren Darussurur Pusat, 19 Mei 2018. Menurut Nina H. Lubis, kebanyakan santri-santri pondok pesantren di Cimahi kebanyakan adalah "santri kalong" sehingga sebagaian besar pondok pesantren di Cimahi hanya memiliki sedikit "santri mukim", hal ini tentu berbeda dengan pondok pesantren yang ada di pedesaan Jawa Timur misalnya yang memiliki santri hingga mencapai ribuan (santri mukim). Lihat Nina Herliana Lubis, Sejarah Kota Cimahi..., hlm. 227.

75 Alfatih Muhammad, 2013, Sejarah Singkat YPP Darussurur, wordpress.com, diakses melalui https://smkdarussurur.wordpress.com/, pada tanggal 10 Mei 2018, Pukul 12.39 WIB. 
SD, SMP, SMK Plus yang pada umumnya menerapkan sistem perpaduan antara kurikulum Pesantren dan Diknas. ${ }^{76}$ Hingga secara keseluruhan hingga hari ini, telah ada 40 cabang Pondok Pesantren Darussurur baik di dalam maupun luar Cimahi, seperti Garut, Sukabumi, Tasik, Cianjur, Jakarta, Bekasi, Indramayu, Bogor, Palembang, yang tidak terdata secara menyeluruh. ${ }^{77}$

Dakwah melalui ceramah keagamaan (1947-2009), proses dakwah K.H. Muhammad Yahya dihadapan masyarakat secara langsung dilakukan dengan ceramah keagamaan seiring pada tahun 1947 beliau mendirikan pondok pesantren dan majelis ta'lim, seperti kajian, khutbah, dan konsultasi pribadi, karena banyak masyarkat yang datang pada beliau mengungkapkan berbagai permasalahan dalam hidup, memohon nasihat dan solusi dari seorang alim ulama, selain itu adapula yang meminta pekerjaan, uang, jodoh, dan lain sebagainya yang berkenaan dengan problematika hidup. ${ }^{78}$

Beliau memiliki jadwal yang padat terkait aktivitas dakwahnya di pondok pesantren, sebagian besar waktunya tercurahkan untuk berdakwah. Dalam proses aktivitas dakwahnya banyak undangan dakwah untuk beliau, meskipun lelah beliau menjalani dan mengemban tugas dan peranannya sebagai seorang ulama dengan sepenuh hati dan kesungguhan.

Salah satu media dakwah yang sering digunakan dan cukup luas dikenal salah satunya adalah dakwah bi al-lisan atau dakwah dengan ucapan, atau secara umum disebut juga ceramah. Dakwah beliau tidak hanya sekedar mendidik dan mengajar di pesantren, beliau juga aktif mengisi ceramahceramah keagamaan seperti pengajian ta'lim dan khutbah, beliau juga banyak diundang untuk mengisi acara-acara besar seperti isrami'raj, muludan, dan haol di berbagai daerah, seperti Cimahi, Jakarta, Bogor, Karawang, dan Malang. ${ }^{79}$

Ta'lim dan pengajian rutin pun turut mewarnai aktivitas ceramah keagamaannya di Cimahi, seperti di Pondok Pesantrennya, di Majelis Ta'lim al-Idris di Panyaweuyan, Masjid KUA Cimahi, dan Maqom Qomar di Utama, yang secara keseluruhan yang mengikuti ta'lim merupakan masyarkat umum kota Cimahi. ${ }^{80}$ Materi ceramah keagamaan K.H. Muhammad Yahya meliputi ajaran keislaman pada umumnya, namun beliau lebih menekankan pada permasalahan hati, baik kebersihan hati (tadzkiyatun nafs) dan makrifatullah,

\footnotetext{
${ }^{76}$ Jalaluddin Sayuthi, Laki-laki, 65 tahun, Menantu dan Pengurus SD, SMP, SMK Plus Darussurur, Cimahi: Mushola SMP Plus Darussurur, 23 Juni 2019.

77 M. Sulaeman Jazuli, Laki-laki, 47 tahun, Anak ke-15, Bandung: Pondok Pesantren Darussurur Pusat, 19 Mei 2018.

78 Jalaluddin Sayuthi, Laki-laki, 65 tahun, Menantu dan Pengurus SD, SMP, SMK Plus Darussurur, Cimahi: Mushola SMP Plus Darussurur, 23 Juni 2019.

79 M. Sulaeman Jazuli, Laki-laki, 47 tahun, Anak ke-15, Bandung: Pondok Pesantren Darussurur Pusat, 19 Mei 2018.

${ }^{80}$ Muhammad Samsudin, Laki-laki, 63 tahun, Kuncen Maqam Qomar, Cimahi: Maqam Qomar Utama, 22 Februari 2019.
} 
juga masalah kenikmatan dan bersyukur kepada Allah, ${ }^{81}$ yang secara umum materi dakwah beliau lebih banyak menyangkut akhlak dan ketauhidan dalam mendidik masyarakat dan sasaran dakwahnya, yang tentunya turut mempengaruhi kultur religiusitas keislaman dan perubahan sosial pada moral yang berkembang di masyarakat sekitarnya, terkhusus masyarakat kota Cimahi kearah yang tentunya lebih baik dan positif.

Dakwah melalui tarekat (1960-an), salah satu sarana dan media dalam internalisasi dakwah yang juga biasa dilakukan oleh seorang Ulama, Da' I, atau Kyai adalah Tarekat, dimana Tarekat ini sudah dikenal sejak lama dan dapat dikembangkan sebagai media dalam metode dakwah, sebagai alat dalam mengkomunikasikan nilai-nilai ajaran Islam. Tarekat secara umum memuat praktik makrifatullah yang selalu mengingatkan jamaahnya untuk mendekat dan mengenal tuhannya. Tarekat dan Tasawuf sendiri sebenarnya telah digunakan oleh para ulama dan wali-wali terdahulu sebagai media dan saluran dalam melakukan dakwah serta Islamisasi di Nusantara, terkhusus pulau Jawa.

Dan salah satu kyai yang menggunakan Tarekat sebagai sarana dakwah bagi jamaahnya sebagai implementasi dalam ketauhidan dan makrifatullah adalah K.H. Muhammad Yahya. Selain mendidik dan ceramah, sebagai seorang Mursyid Tarekat (TQN) yang berguru kepada K.H. Muhammad Zaenuddin Abu Tolhah, dan telah melewati tujuh latifah, yaitu dari latifah qalbi, ke latifah ruh, ke latifatul sirri, ke latifah khafi, ke latifatul akhfa, ke latifatun nafsi, hingga ke latifatul kullu dimana seluruh badan berdzikir dari ujung rambut sampai ujung kaki, dalam proses beliau menjadi seorang khalifah atau mursyid tarekat, ${ }^{82}$ beliau tentunya memiliki kewajiban dan tugas untuk mengajarkan dan mengembangkan terakatnya, termasuk di pondok pesantrennya Darussurur yang beliau bangun. Beliau turut mengajarkan tarekat kepada jamaahnya, yang mau berbai'at dan mengambil ijazah kepadanya, namun, tidak berlangsung lama di tahun 1960-an, kajian tarekat beliau pun dikenal tertutup (privasi) hanya pada kalangan terbatas, yang mau dan serius dalam berkhidmat. Kitab yang menjadi rujukan beliau adalah kitab Fathul Arifin, ${ }^{83}$ dan amalan serta kegiatan jamaah tarekat beliau seperti amalan dan kegiatan jamaah TQN lainnya yang bersanad pada Syekh

${ }^{81}$ M. Sulaeman Jazuli, Laki-laki, 47 tahun, Anak ke-15, Bandung: Pondok Pesantren Darussurur Pusat, 19 Mei 2018.

${ }^{82}$ Rekaman Haol Buya Yahya yang ke IX, Pengangkatan Abuya Abuya K.H. Muhammad Yahya sebagai Mursyid Tariqah Qadiriyah wa Naqsabandiyah oleh K.H. Thahir, Rekaman Tanggal 13 Mei 2018.

${ }^{83}$ Jalaluddin Sayuthi, Laki-laki, 65 tahun, Menantu dan Pengurus SD, SMP, SMK Plus Darussurur, Cimahi: Mushola SMP Plus Darussurur, 23 Juni 2019. 
Achmad Khatib Sambas, seperti dzikir, muroqobah (kontemplasi), dan manaqiban. ${ }^{84}$

Dakwah beliau melalui tulisan (1979-2009), K.H. Muhammad Yahya dikenal produktif dalam menulis, terlebih dalam menulis dan menerjemahkan kitab-kitab berbahasa Arab kedalam nadhom Sunda, yang tentunya turut andil dalam transmisi intelektual keislaman dan berperan dalam mempermudah masyakrat yang tidak dapat memahami bahasa Arab dalam mempelajari kitabkitab klasik, bahkan beliau telah meringkasnya agar dapat mudah dipahami. Beliau dikenal telah mulai menulis sejak masih muda, namun bukti tahun penulisan nadhomnya tidak dapat dipastikan, diantara buah pena beliau antara lain terbagi kedalam beberapa bidang keislaman seperti, seperti bidang tauhid, akhlak, tasawuf, tafsir, dan juga bidang fiqh. ${ }^{85}$ Dalam bidang Aqidah dan Tauhid, yaitu: Nadhom Aqidatul Awam (merupakan terjemahan dari kitab Mazmumat Aqidatul Awam karangan Syekh Marzuki tahun 1326 H, yang membahas mengenai dasar-dasar aqidah dalam Islam), Nadhom Syuabul Iman (merupakan terjemahan dari kitab Syu'ab al-Iman karangan Syekh Zainuddin, yang membahas mengenai 77 cabang keimanan), Nadhom Qasidah al-Habib Abdullah (merupakan terjemahan dari Qasidah Ya Arhamar Rahimin karangan Sykeh Abdullah, yang merupakan nasihat-nasihat dan syair pujipujian kepada Allah), Nadhom Tujuh Golongan (merupakan terjemahan Hadist Riwayat Abu Hurairah, mengenai tujuh golongan yang mendapat naungan Allah SWT) ${ }^{86}$

Bidang Akhlak dan Tasawuf, yaitu: Nadhom Azkya (merupakan terjemahan dari kitab Hidayatul Azkiya ila Thariqil Awliya karangan Syekh Zaenuddin, yang membahas mengenai wasiat-wasiat dalam menempuh jalan kebahagiaan untuk sampai (wushul) kepada Allah SWT), Nadhom Wasiat Habib Abdullah al-Hadad (merupakan wasiat yang diberikan oleh Habib Abdullah kepada K.H. Muhammad Yahya agar senantiasa bertakwa kepada Allah SWT), Nadhom Jumlah Niat Ngaji (Karangan K.H. M. Yahya yang membahas mengenai jumlah niat dalam mengaji atau menuntut ilmu yang semuanya ada tujuh), Nadhom Adab Ka Indung Bapak (merupakan terjemahan kitab Kifayatul Mubtadiin pada bab adab, yang membahas mengenai adabadab seorang anak terhadap orangtuanya), Nadhom Sateuacan Kulem (Karangan K.H. M. Yahya pada hari Ahad Zumadil Akhir tahun 1400 H, membahas mengenai do'a yang dibaca sebelum tidur), Nadhom Lawang Setan

${ }^{84}$ Marwan Salahudin, Amalan Tarekat Qadiriyah Wa Naqsabandiyah sebagai Proses Pendidikan Jiwa di Masjid Babul Muttaqin Desa Kradenan Jetis Ponorogo, (UIN Sunan Ampel Surabaya: Jurnal Esoterik, Vol. 2 No. 1, 2016), hlm. 67.

${ }^{85}$ Majalah al-Kisah, Kisah Ulama Buya K.H. M. Yahya Bandung: Ulama Amilin Bukan Ulama “Ambilin”, (Jakarta:PT. Dian Rakyat Jakarta, Edisi 6 tahun 2013), hlm. 56.

${ }^{86}$ Muhammad Abd al-Qadir bin K.H. Abdullah Qasim Shaleh, Mazmu fi al-Nadhomati alArobiyah Darussurur, (Bandung: Ma'had Darussurur). 
(Karangan K.H. M. Yahya yang membahas mengenai pintu-pintu yang menjadi jalan masuknya setan pada diri dan hati manusia), Nadhom Sifat Mahmudah Sareng Madzmumah (Karangan K.H. Muhammad Yahya mengenai penjelasan sifat-sifat Mahmudah/baik dan Madzmumah/tercela), Nadhom Anjuran Maca Kitab Ihya Ulumuddin (merupakan terjemahan tuturan Sayyid Abdullah al-Hadad yang menuturkan anjuran-anjuran untuk membaca kitab Ihya), Nadhom Du'a Isromi 'raj (karangan K.H. M. Yahya pada 28 Rajab $1418 \mathrm{H}$, yang berisi didalamnya do'a-do'a yang dipanjatkan di waktu memperingati Isro Mi'raj). ${ }^{87}$

Bidang Tafsir dan al-Qur'an, yaitu: Nadhom Fadhilah al-Fatihah (karangan K.H. M. Yahya mengenai manfaat mendawamkan al-Fatihah setelah selesai shalat), Nadhom Jurumiyah Sunda (merupakan terjemahan dari Kitab Jurumiyah karangan Syekh Shonhaji, yang berisi mengenai dasar-dasar mempelajari Bahasa Arab), Nadhom Fadhilah Lailatul Qadr (karangan K.H. M. Yahya yang menjelaskan mengenai keutamaan-keutamaan dimalam Lailatul Qadr). Keempat, Bidang Fiqh, yaitu: Nadhom Saum Ramadhan (merupakan karangan K.H. Muhammad Yahya yang berisi mengenai beberapa hal mengenai tatacara puasa Ramadhan), Nadhom Saum Arafah (merupakan karangan K.H. M. Yahya yang membahas mengenai Puasa Arafah), Nadhom Dosa Leutik Jadi Gede (merupakan karangan K.H. M. Yahya yang berisi mengenai apa-apa saja dan bagaimana dosa kecil dapat menjadi dosa besar), Nadhom Hukum Nikah (karangan K.H. M. Yahya yang membahas terkait pernikahan, baik hukum dan tujuan menikah), Nadhom Sunah Wudhu (karangan K.H. M. Yahya yang menjelaskan mengenai amalan-amalan apasaja yang disunahkan berwudhu, seperti membaca al-Qur'an). ${ }^{88}$

\section{Simpulan}

Uraian diatas menggambarkan mengenai aktivitas dakwah yang dilakukan oleh seorang ulama lokal yang berasal dari Cimahi, yakni K.H. Muhammad Yahya, yang merupakan seorang tokoh agamawan, mursyid thariqah, dan elite pemerintahan, yang secara keilmuan memiliki kemapanan dan keunikan tersendiri. Terlebih aktivitas dakwah yang beliau lakukan yang terdiri dari berbagai sisi baik pendidikan, sosial, keagamaan dan juga dakwah keislaman, yang masing-masing termanifestasi dari beberapa media dakwahnya, yaitu dakwah melalui lembaga pendidikan (1947-2009), dakwah melalui ceramah keagamaan (1947-2009), dakwah melalui thariqah (TQN) (1960-an), dan dakwah melalui karya tulis (1979-2009).

\footnotetext{
${ }^{87}$ Muhammad Abd al-Qadir bin K.H. Abdullah Qasim Shaleh, Mazmu fi al-Nadhomati alArobiyah Darussurur, (Bandung: Ma'had Darussurur).

${ }^{88}$ Muhammad Abd al-Qadir bin K.H. Abdullah Qasim Shaleh, Mazmu fi al-Nadhomati alArobiyah Darussurur, (Bandung: Ma'had Darussurur).
} 
Aktivitas Dakwah K.H. M Yahya...... | Hendro Kartika

\section{Daftar Pustaka}

\section{Buku}

Bachtiar, Wardi. 1997. Metodologi Penelitian Ilmu Dakwah. Jakarta: Logos Wahan Ilmu.

Buya Anom, Biografi Syeikhina Abuya KH Muhammad Yahya bin KH Muhammad Azhari. Pondok Pesantren Darussurur.

Dhofier, Zamakhsyari. 2011. Tradisi Pesantren. Jakarta: LP3ES.

Habib, Syafa'at. 1992. Buku Pedoman Dakwah. Jakarta: Wijaya.

Hasbullah, Moeflich. 2012. Sejarah Sosial Intelektual Islam di Indonesia. Bandung: Pustaka Setia.

MS, Mawardi. 2008. Sikologi Dakwah: Kajian Teori Sosiologi, al-Qur'an, dan al-Hadits. Ponorogo: Uwais Inspirasi Indonesia. 
Munzier dan Harjani. 2009. Metode Dakwah. Jakarta: Kencana.

Natsir, M. 1979. Fungsi Dakwah Islam dalam Rangka Perjuangan. Jakarta: Media Dakwah.

S. Susanto, Astrid. 1985. Pengantar Sosiologi dan Perubahan Sosial. Binacipta: IKAPI.

Shalahuddin dan Iskandar. 2003. 100 Tokoh Islam Paling Berpengaruh di Indonesia. Jakarta: Intimedia Ciptanusantara.

Sugono, Dendy. 2008. Kamus Bahasa Indonesia (KBBI). Jakarta: Pusat Bahasa Departemen Pendidikan Nasional.

Sulasman. 2014. Metode Penelitian Sejarah. Bandung: Pustaka Setia.

Stamford Raffles, Thomas. 2008. The History of Java. Yogyakarta: Penerbit Narasi.

Muhammad Abd al-Qadir bin K.H. Abdullah Qasim Shaleh. Mazmu fi alNadhomati al-Arobiyah Darussurur. Bandung: Ma'had Darussurur.

\section{Karya tulis}

Andryyanti, Marlyn, 2017, "Makna Maulid Nabi Muhammad SAW", Skripsi, UIN Makasar.

Anjar R, Ari, 2018, "Biografi Sejarah dan Pemikiran K.H. Muhammad Kurdi Mama Cibabat Cimahi (1839-1954)", Jurnal Historia Madani, UIN Bandung.

Iswanto, Agus, 2013, "Sejarah Intelektual Uslam Nusantara: Reformulasi Tradisi di Tengah Pembaharuan", Jurnal Lektur Keagamaan, Balai Litbang Agama Jakarta.

Majalah al-Kisah, Edisi 6, 2013, "Kisah Ulama Buya K.H. M. Yahya Bandung: Ulama Amilin Bukan Ulama “Ambilin”, Majalah, PT. Dian Rakyat Jakarta.

Nasution, Yasir, 2014, "Peran Strategis Ulama dalam Pengembangan Ekonomi Syariah", Jurnal Human Falah, IAIN Surakarta.

Pramita, Valeria, 2014, "Resume Tasawuf III: Wirid-wirid Para Sufi", Skripsi, IAIN Imam Bonjol.

Salahudin, Marwan, 2016, “Amalan Tarekat Qadiriyah Wa Naqsabandiyah sebagai Proses Pendidikan Jiwa di Masjid Babul Muttaqin Desa Kradenan Jetis Ponorogo", Jurnal Esoterik Vol. 2 No. 1, 2016, UIN Sunan Ampel Surabaya.

\section{Internet}

Abdkadiralhamid. 2013. "Biografi Habib Abdullah bin Abdul Qadir Bil Faqih al Alawi, Malang, Jawa Timur", diakses melalui http://ahlulbaitrasulullah.blogspot.com/, pada tanggal 13/2/2019, pukul 19:23 WIB. 
Alfatih Muhammad. 2013. "Sejarah Singkat YPP Darussurur", wordpress.com, diakses melalui https://smkdarussurur.wordpress.com/, pada tanggal 10 Mei 2018, Pukul 12.39 WIB.

Astana Gunung Djati Cirebon. "Sejarah Syaikh Tolhah", diakses melalui http://tqn-cirebon.blogspot.com/, pada tanggal 13/2/2019, pukul 19:04 WIB.

Dhimas Ragil. "Biografi Sayyid Abbas bin Alwi al-Maliki", diakses melalui http://syukronmaba.blogspot.com/, pada tanggal 13/2/2019, pukul 19:54 WIB.

Ensiklopedia NU. "Sayyid Alwi bin Abbas al-Maliki", diakses melalui http://wiki.laduni.id/, pada tanggal 13/2/2019, pukul 19:56 WIB.

Hafidz Muftisany, Sorogan dan Bandongan Metode Khas Pesantren, diakses melalui https://republika.co.id/, pada tanggal 23 Juni 2019, Pukul 10.11 WIB.

MuslimMN. 2014. "K.H. Raden Muhammad Zarkasyi (Mama Eyang Cibaduyut)", diakses melalui https://pustakamuhibbin.blogspot.com/, pada 13/02/2019, pukul 13:50 WIB.

Pondpes al-Mu'awanah. 2012. "Pesantren al-Mu'awanah-Cianjur Selatan", diakses melalui https://pondpesalmuawanah.blogspot.com/, diakses pada 12/2/2019 pukul 14:36 WIB.

Sejarah Cirebon. "Keturunan Sunan Gunung Djati dari Istri-istrinya", diakses melalui https://historyofcirebon.id/, pada tanggal 18 Juni 2019, pukul 21:11 WIB.

\section{Wawancara}

K.H. Jalaluddin Sayuthi, (65 tahun). Menantu dan Pengurus SD, SMP, SMK Plus Darussurur. Wawancara, Cimahi: Mushola SMP Plus Darussurur, 23 Juni 2019.

K.H. M. Sulaeman Jazuli (47 tahun). Anak ke-15. Wawancara, Bandung: Pondok Pesantren Darussurur Pusat, 19 Mei 2018.

Muhammad Samsudin (63 tahun). Kuncen Maqam Qomar. Wawancara, Cimahi: Maqam Qomar Utama, 22 Februari 2019.

Siti, (51 tahun). Masyarakat sekaligus jamaah dari K.H. Muhammad Yahya. Wawancara, Bandung: Kediaman Beliau, 22 Januari 2019.

Ustadz Irfan (34 tahun). Cucu K.H. Muhammad Yahya, Bandung: Pondok Pesantren Darussurur 27. Wawancara, 23 Februari 2019.

\section{Audio Visual}

Muhammad Abubakar, Sekelumit Biografi Abuya K.H. Muhammad Yahya r.a. oleh K.H. Muhyiddin Abdulqodir al-Manafy (Darussurur), 
Aktivitas Dakwah K.H. M Yahya...... | Hendro Kartika

Youtube.com, Dipublikasikan pada 26 Mei 2017, Maqam Qomar Utama Cimahi, diakses pada 8 Mei 2018.

Rekaman Haol Buya Yahya yang ke IX, Pengangkatan Abuya Abuya K.H. Muhammad Yahya sebagai Mursyid Tariqah Qadiriyah wa Naqsabandiyah oleh K.H. Thahir, Rekaman Tanggal 13 Mei 2018. 
Aktivitas Dakwah K.H. M Yahya....... | Hendro Kartika 